\title{
TREE-MOULD CAVES IN SLOVAKIA
}

\author{
Ludovít GAÁL 1
}

\section{SUMMARY}

Four tube-shaped caves are described in this work, which origined in consequence of weathering the trees. Their length ranges from 5.8 to $17 \mathrm{~m}$. All of them occur in neovolcanic rocks of Middle Slovakia, in epiclastic andesite conglomerates, breccias or in the tuffs. Some other caverns are close to the entrance of this caves, however they are inaccessible for a man. Thin rim of silicates (opal or chalcedony) occurs in some of them.

Keywords: caves, tree-mould, opal, chalcedony, andesite, weathering.

The caves originated by weathering of trees in several parts of the world are known rarely (see e.g. Tsuya 1971). In Slovakia, they occur in volcanic tuffs or andesite breccias and conglomerates of the subsequent Neogene volcanism. This voluminous volcanism was generated after the Alpine orogenesis of the West Carpathians in the Middle Miocene (Badenian, Sarmatian) mainly in Middle and East Slovakia. It had several eruption centres. Among them the largest is strata-volcano Polana in the Middle Slovakia (Gaál, 2002).

The first tree-mould cave was described just from the Polana Mountains (Gaál 1993). The little cave named Jaskyňa pod Jaseňovym vrchom with the length of $5.8 \mathrm{~m}$ was found by Vítek (1990). It is developed in the Middle Miocene volcanic breccias and conglomerates. The little threshold in the bottom of the first third of the cave prevents the transport of waste out of the cavity; therefore it could not originate by weathering. The several short ceiling and lateral offshoots are in the back part of the cave, which probably formed from tree branches. Some sim-

Fig. 1 - Map of the cave Jaskyña pod Jaseňovŷ̀ vrchom (Gaál, 2002)

${ }^{1}$ Slovak Caves Administration -Hodzòva, 11 - 03101 Liptovsky Miknlas Slovakia

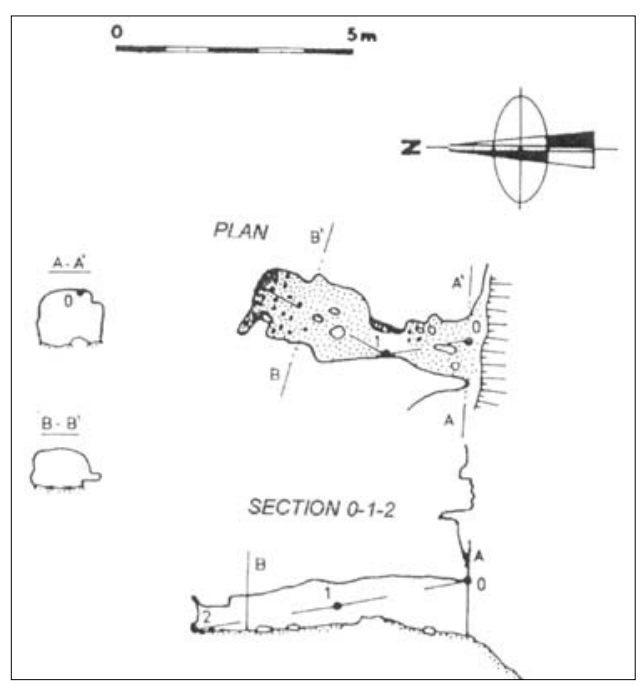


ilar small pipe-shaped cavities are around the cave entrance as well. They have diameters of 3, 8, 14, 15 and $50 \mathrm{~cm}$. Some of them have a rim of white silicon (probably chalcedony).

The other tree-mould cave was found in 2002 in the South Slovakia near the village Săhy. Primarily it was described by Burkhardt (1962) as suffose cave named Jaskyna $\mathbf{v}$ tufoch. It has the entrance with dimensions of $2.1 \mathrm{~m}$ (width) $\times 0.7 \mathrm{~m}$ (height), from where three tube-shaped parallel cavern branch to the direction NESW. The longest of them has $8 \mathrm{~m}$ length with an oval cross-section of $97 \times 51 \mathrm{~cm}$. Well-preserved silicified moulds of tree bark are found on its walls. Some small fragments of the silicified trees occur among the waste of the cavern bottom. Some of them are completely impregnated by dark coloured chalcedony or opal, but the original structure of tree can be discerned. The other cavern has a length of $3 \mathrm{~m}$ with an oval cross-section of $92 \times 44 \mathrm{~cm}$. The cross-section of the smallest cavern has only

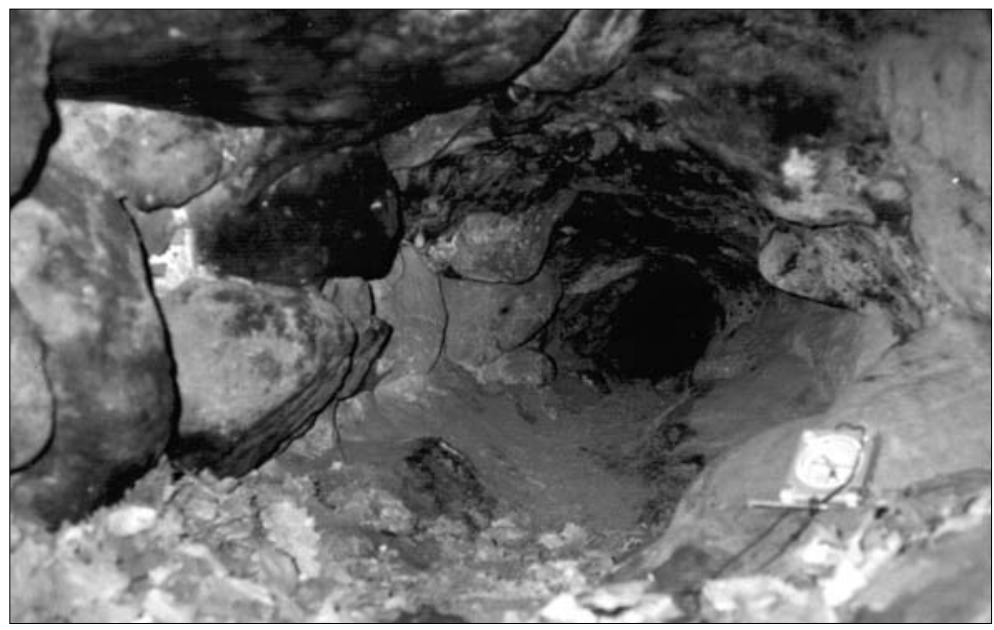

Fig. 2. Detail of carbonised tree trunk mould in the cave Jaskyña v tufohy. Photo: L. Gaál.

$48 \times 32 \mathrm{~cm}$. The total length of caverns is $17 \mathrm{~m}$. The caverns are surrounded by finegrained tuffs with a thickness of $0.6 \mathrm{~m}$. Above them, there are andesite breccias of pyroclastic flow with fragments of $0.5 \mathrm{~m}$, which are buried by coarse-grained breccias with fragments of $0.5 \mathrm{~m}$.

Radinger and Mlejnek (2001) described two very typical tree-mould caves named Trpasličia jaskyňa and Pecna. The first of them is developed in coarse epiclastic andesite conglomerate of the Krupinska planina Plateau. The length of the tubeshaped cavern is $11.9 \mathrm{~m}$, the dimensions of the oval entrance are at first $1.2 \times 1.5 \mathrm{~m}$, after a few meters $0.8 \times 0.7 \mathrm{~m}$ and at the end the cavern narrows down to several $\mathrm{cm}$. Some other caverns are close to the entrance, however they are inaccessible for a man. Their length is between $0.15-7.7 \mathrm{~m}$, diameter between 3 and $40 \mathrm{~cm}$. Thin rim of silicates occurs in some of them. 


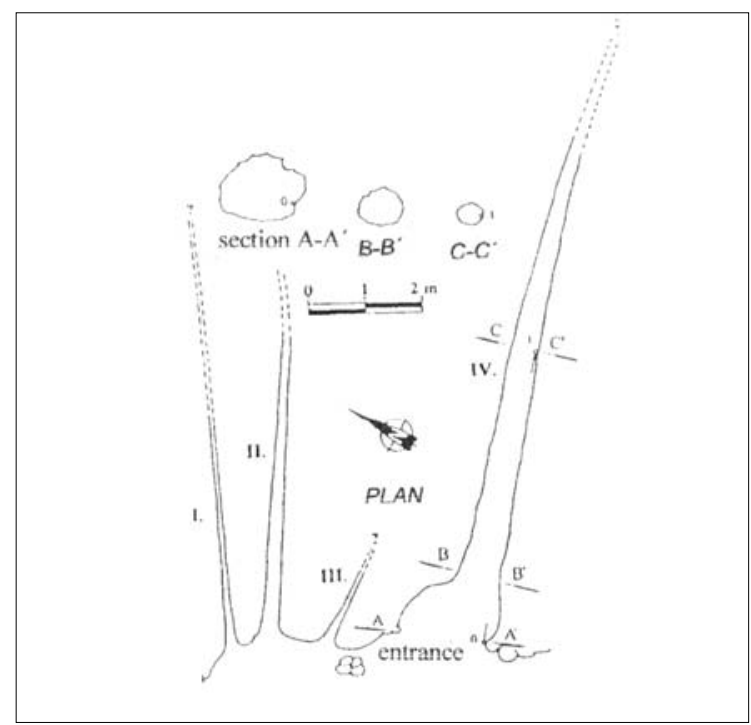

Fig. 3. Map of the cave Trpasličia jaskyňa by F. Radinger (2001).

Pecna is situated in Lučenská kotlina basin in the Southern Slovakia and has a similar geologic position as the Trpasličia jaskyňa cave. Its entrance and the first part are probably extended manually. A little cavern, probably of tree branch origin, with the length of $65 \mathrm{~cm}$ and the cross-section of $13 \times 9 \mathrm{~cm}$ occurs in the end of $6.1 \mathrm{~m}$ long corridor. Some others similar cavities with diameter 3-5 cm occur around the entrance.

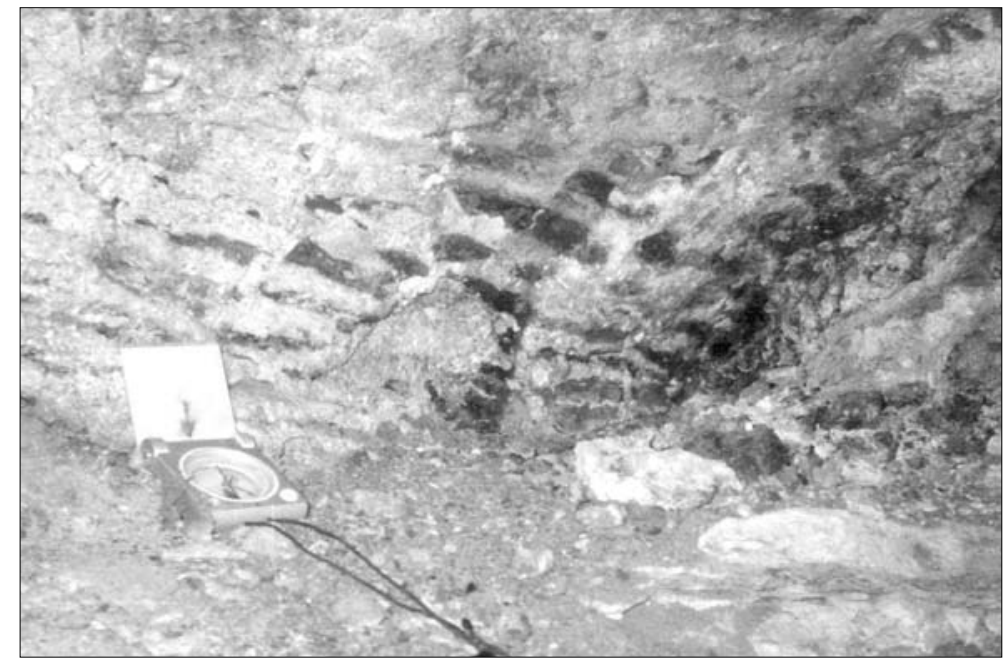

Fig. 4. Characteristic tube shape of the passage in the cave Trpasličia jaskyña. Photo: L. Gaál 
According to the geological position of the Pecna Cave and Trpasličia jaskyña, with chaotic bedded coarse epiclastic andesite conglomerates, we can suppose the high kinetic energy of the wild stream, what carried along the coarse andesite fragments and trees to a longer distance. The distance of the Pecna Cave from Miocene volcanic centre Lysec is $11.5 \mathrm{~km}$, the Trpaslicia jaskyña is situated $14 \mathrm{~km}$ away from the eruption centre Celovce (however the trees were not drifted to this distance, because no trees grew in the surrounding of the volcano). Trpasličia jaskyña has a similar orientation as volcanic slope (E and NE).

The trees were relatively rapidly covered by sand, gravel or ash, generally without oxygen. Their disintegration starts by following reaction:

$\left(\mathrm{C}_{6} \mathrm{H}_{10} \mathrm{O}_{5}\right)_{\mathrm{n}} \rightarrow \mathrm{nCO}_{2}+3 \mathrm{nH}_{2} \mathrm{O}+\mathrm{nCH}_{4}+4 \mathrm{nC}$

then $\mathrm{CO}_{2}+\mathrm{H}_{2} \mathrm{O} \rightarrow \mathrm{H}_{2} \mathrm{CO}_{3}$

The aggressive silicic acid induces disintegration of silicate, which occurs as salts of $\mathrm{Na}, \mathrm{K}, \mathrm{Mg}$ etc. For example:

$\mathrm{Na}_{2} \mathrm{SiO}_{3}+\mathrm{H}_{2} \mathrm{CO}_{3} \rightarrow \mathrm{H}_{2} \mathrm{SiO}_{3}+\mathrm{Na}_{2} \mathrm{CO}_{3}$

$\mathrm{Na}_{2} \mathrm{CO}_{3}$ floated out by water, and the silicic acid transforms into the silicic gel:

$\mathrm{H}_{2} \mathrm{SiO}_{3} \rightarrow \mathrm{SiO}_{2}+\mathrm{H}_{2} \mathrm{O}$

This gel incrusts in colloid form the relatively soft part of the trees - mainly their bark. Later, the gel transforms to the amorphous opal or to cryptocrystallic chalcedony. After some time, the inner part of trees rots and is carried-out by weathering. The crust of chalcedony or opal preserves the cavity against collapsing. The chalcedony crust flakes off in greater cavities and then is weathered out, but in smaller cavities is well preserved and remains.

The caves Jaskyňa pod Jaseňovym vrchom and Jaskyňa $v$ tufoch are situated relatively nearer to the eruption centre. In this place the ash could be hot, and the lixiviation of silicic acid is quicker. The tree can be also burnt by hot pyroclastic material. The partly or completely carbonised tree may be easily penetrated by silicic acid, which transforms to opal or chalcedony. Their colour can then often be darkened by carbon. Such fragments of dark chalcedony occur in the cave Jaskyňa $v$ tufoch.

The tree-mould caves, even though their small proportions, are very valuable for paleogeography of vulcanites. It is necessary to pay increased attention and protection to them.

\section{Acknowledgements}

In the end, I would like to thank to Peter Gažík, Stanislav Jeleň, Anton Kerti and František Radinger for offering the data and assistance. 


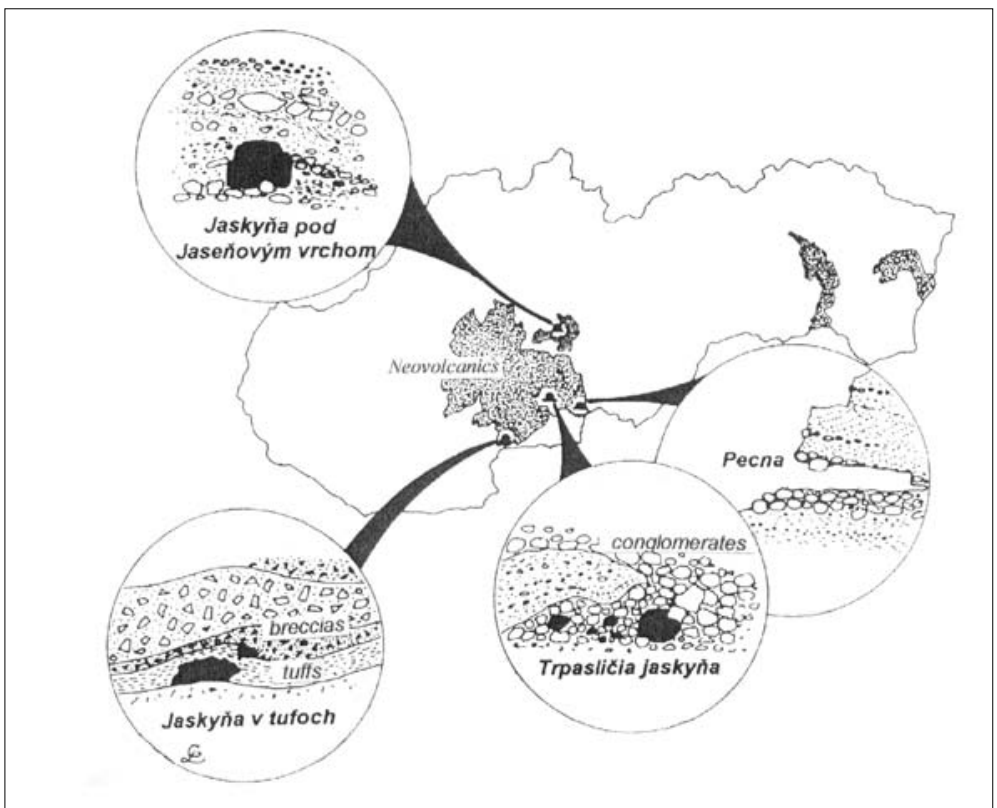

Fig. 5. Location of tree-mould caves in neovulcanic rocks in Slovakia with details of their sedimentation environment.

\section{References}

BURKHARDT R. 1962 - Jaskyňka v tufech u Šahu na Slovensku. Československy kras 13, Praha: 219-220.

GAÁL L. 1993: Jaskyña pod Vel'kym Jasenym - novy geneticky typ pseudokrasovej jaskyne na Slovensku. Sinter 1, Liptovsky Mikulás: 14.

GAÁL L. 2002: Prispevok k vzniku jaskýň následkom vyvetrávania stromov. Vyskum, využívanie a ochrana jaskýň. 3. Vedecká konferencia s medzinárodňou účast'ou pri príležitosti, Stará Lesná 14-16 Nov. 2001, Liptovsky Mikulás: 58-63.

RADINGER F. \& MLEJNEK R. 2001: Nové pseudokrasové jaskyne v geomorfologicklych celkoch Juhoslovenská kotlina, Krupinská planina a Ostrôzky. Spravodaj SSS 32, 3, Prešov: 11-15.

TSUYA H. 1971: Topography and Geology of Volcano Mt. Fuji. In: Fuji-san, Tokyo: 132-149.

VÍTEK J. 1990: Jaseňovy vrch pod Pol’anou. Krásy Slovenska, 67, 3, Bratislava: 40-41.

Received: 23 february 2003

Accepted: 12 april 2003 